\title{
Hydrolytic enzyme levels in malted cereals
}

\author{
Mohammed Adamu Milala*, Emmanuel Othumba Addy \\ Biochemistry Department, Faculty of Science, University of Maiduguri, Borno State, Nigeria
}

Email address:

mohammedmilala@yahoo.com (M. A. Milala)

\section{To cite this article:}

Mohammed Adamu Milala, Emmanuel Othumba Addy. Hydrolytic Enzyme Levels in Malted Cereals. Advances in Biochemistry. Vol. 2, No. 5, 2014, pp. 76-79. doi: 10.11648/j.ab.20140205.14

\begin{abstract}
Six grain samples namely barley, maize, millet, rice, sorghum and wheat were tested for enzyme levels (amylase, protease and lipase) in order to assess their malting characteristics, using barley as a standard. The levels of the enzymes were estimated in the whole dry grains, $24 \mathrm{~h}$ steeped, $24 \mathrm{~h}$ sprouted and $48 \mathrm{~h}$ sprouted grains. A combined statistical analysis of linear regression and analysis of variance were used to test for enzyme interaction, similarities and interspecific relationship between the cereals. The estimated interspecific relationship between sorghum and barley was $84 \%$ based on the three enzymes, while millet had $75 \%$. All the sprouted cereals with the exception of the standard barley had high lipase levels. This possibly suggests certain limitations as regards to production of off-flavours. Malt prepared from maize, sorghum, rice and millet had comparable protease levels with barley $(\mathrm{P}>0.05)$. The malts prepared from maize, millet, rice, sorghum and wheat had comparatively low alpha-amylase levels when compared with the standard barley. Multiple linear regressions showed amylase was dependent on lipase and protease. The relationship was not affected by either soaking (steeping) or sprouting of the grains. The implications of these findings suggest that a combination of these cereals might give good malt for food applications.
\end{abstract}

Keywords: Amylase, Lipase, Protease, Malting, Cereals

\section{Introduction}

The main objective of malting is to promote synthesis of hydrolytic enzymes which will solubilize large macromolecules into low molecular weight compounds of desired characteristics. Malting is the limited germination of cereal grains or, occasionally, the seeds of pulses (peas and beans), under controlled conditions with the primary objective of promoting the development of hydrolytic enzymes [1-2]. The malting process involves germination and growth resulting in the development of enzymes which degrade the reserved food materials in the endosperm of the grain. Malting induces important beneficial biochemical changes in sorghum grains especially. Indeed, soaking/steeping generates grain softening and increases water availability [3]. The enzymes produced during germination lead to the hydrolysis of starch and proteins with release of sugars and amino acids directly available.

Several types of cereals have been used for malting. The malting potentials of different cereals have been studied from time over the time [4]. Malts from wheat, sorghum and maize have been studied with respect to their use in food formulation and also as brewing adjuncts [5]. Malting of barley is a recognized process associated with beer production. The conversion of barley into beer represents mankind's oldest and most complex example of applied enzymology. Indeed, historically some of the most significant advances in enzymology have been linked to the world of brewing. Analysis of invertase in determining the factors that a bearing on the quality of beer, brewers have learned not only how the endogenous enzymes contribute to issues such as fermentability, filterability, foam, clarity, but also flavor [6].

However, the selection of any grain for good malting characteristics is based on the criteria that it will be suitable for processing and would yield the desired flavour qualities or characteristics. There are different physical and chemical criteria used in defining high and low grade malt [7]. A few of such tests include; germination energy, embryo growth, endosperm sedimentation score, enzyme potentials and protein content. Proteolytic enzymes improve amino acid availability, particularly lysine, methionine and tryptophan that are lacking in cereals.

This paper reports the use of a combined assessment of some hydrolytic enzymes (amylase, protease and lipase) for predicting the malting characteristics of some cereals grown in Nigeria especially north eastern region. Six types of cereals namely barley, maize, rice; sorghum and wheat were 
screened for hydrolytic enzymes using barley as a reference standard.

\section{Materials and Methods}

Freshly harvested seeds of the six cereals namely; barley (Hordeum spp. Quite 33 var.), maize (Zea mays, Tzesr-W var.), millet (Penisetum spp. Ex-borno var.), rice (Oriza sativa, dikwa var.), Sorghum (Sorghum bicolor, chakalari var.) and wheat (Triticum spp. Siette ceros var.) were obtained from Lake Chad Research Institute, Maiduguri, Nigeria.

\subsection{Malting}

The seeds were steeped in distilled water at $25 \mathrm{oC}$ for 24hours and then transferred to moistened layer cotton cheese cloth and thereafter allowed to germinate in a dark cupboard at room temperature $25 \mathrm{oC}$ for 48 hours. The sprouted seeds were devegetated, dried at $50 \mathrm{oC}$ in an air conventional oven and stored in air-tight containers at $4 \mathrm{oC}$.

\subsection{Amylase}

The activity of amylase was determined according to the method of [8], based on starch-iodine colour changes. One unit of amylase activity was defined as $A_{0}-A_{t} / A_{o} \times 100$, where $\mathrm{A}_{\mathrm{o}}$ and $\mathrm{A}_{\mathrm{t}}$ were the absorbance of the iodine-starch complex at zero time and after 60 minutes of hydrolysis. Specific activity of amylase was defined as units/mg protein/hour.

\subsection{Lipase}

The lipase activity was determined by the method of [9]. This method estimates the fatty acid produced by the hydrolysis of an olive oil emulsion on which the lipase extract from the cereals had hydrolyzed under optimum conditions of $\mathrm{pH}$ and temperature. One unit of lipase activity was defined as increase in $0.1 \mathrm{ml}$ units of $\mathrm{NaOH}$ titre value over the blank assay.

\subsection{Protease}

Protease level was assayed by the method described by [10]. The free amino acids formed after digestion of a casein substrate was estimated by formol titration. Protease activity was calculated from the equation $(\mathrm{X}-\mathrm{Y}) \mathrm{x} 100$, where $\mathrm{X}$ is the titre value after proteolysis, and $\mathrm{Y}$ is the blank titre value equivalent to the protease free assay.

\subsection{Interspecific Relationships}

The statistical method described by [11] was used. The relationship were estimated as mean deviations from the standard barley values and expressed as percentages.

\section{Results and Discussion}

The results obtained generally showed a wide variations in the various enzyme levels for the different cereals. In general, steeping treatment has been reported to increase enzyme activities. Reported [12] significant increase in diastatic activity when sorghum grains were hydrated for longer periods (40hours) than 24 and 16hours. When compared with barley, lower amylase levels were observed in maize, millet, rice, sorghum and wheat after 48 hours of sprouting. In contrast, the levels of protease were comparable to barley $(\mathrm{P}>0.05)$ with the exception of wheat which notably had the highest value. Lipase in the sprouted maize, millet, sorghum and wheat were comparatively higher than that of barley, while rice had a lower value than the reference standard.

In the malting process, the hard endosperm is enzymically converted into friable malt and alpha amylase plays a crucial role in this respect. Malting of rice increased the quantity of hydrolytic enzymes (amylase, protease) present in them resulting in products that are more nutritious than those kunun-zaki produced without the addition of malted rice [13]. Since starch is the major constituent of the seed, it is expedient that amylase levels could serve as an index for predicting the desired characteristics of good malt. The hydrolytic enzyme (amylase) in the malted cereal aids in digesting the thick slurry thereby converting the complex carbohydrates in the cereal to simple sugars [12]. In line with this, the relationships between the enzymes were statistically investigated by a multiple linear regression, and amylase was found to be dependent on lipase and protease as shown in the equation:

$$
Y_{\text {amylase }}=0.97 X_{\text {lipase }}-0.05 Z_{\text {protease }}-111.85
$$

From the equation, it appears that lipase levels of the cereals is more valuable than protease in predicting the $\alpha$ amylase and hence the friability (soft-texture or ease of crumble ness) of the malt. Structural analysis of most cereals showed that starch granules are enveloped within a lipid vesicle and such lipid barriers can reduce the susceptibility of starch granules to amylolytic digestion [14]. Therefore, high lipase levels should improve the amylolytic conversion of the endosperm starch. Differences in lipase levels of the cereals are possibly due to the site of production of this enzyme during germination. According to [15], sorghum differs from barley with respect to lipase in that this enzyme is only limited to the aleurone layer in barley, while it is produced in both the aleurone and embryo in sorghum. Maize which had the highest levels of lipase in the study may be similar to sorghum.

When lipase and protease were considered again individually in relation to amylase using the simple regression

$$
\begin{gathered}
\mathrm{Y}_{\text {amylase }}=0.12 \mathrm{Z}_{\text {protease }}+123.84(\mathrm{r}=0.15) \\
\mathrm{Y}_{\text {amylase }}=1.91 \mathrm{X}_{\text {lipase }}-288.29(\mathrm{r}=0.65)
\end{gathered}
$$

In consonance with the multiple regressions, the two equations together suggest that lipase is a stronger limiting factor than protease when predicting the friable quality of the malt. Higher lipase activity in cereals may render the malt readily susceptible to lipid peroxidation since the major fatty acids are polyunsaturated derivatives and this lead to the 
production of off-flavour. Therefore it may be advisable to add synthetic food antioxidants to preserve the malt, provided they will not affect the quality of the final product for which the malt is intended.

The interspecific relationship between the cereals based on the three enzymes showed that sorghum has $84.21 \%$ relationship with barley; closely followed by millet (75\%). This observation is in line with the findings of [16] who reported that sorghum had better malting characteristics than other cereals such as maize, millet, or rice. They also found that barley and sorghum exhibited similarities in nitrogen content, protease activity, diastatic activity, extract yield and tannin content.

The basic significance of the interspecific relationship is gene homology within the cereals and results presented suggests a tendency towards greater diversity in gene products (enzymes) as the seeds germinate. Such differences may be due to variation in architectural designs of the seed, with particular reference to organelles responsible for the production of these enzymes. Nevertheless, from a general outlook the interspecific relationship analysis showed that sorghum and wheat are more closely related to barley than rice, maize or wheat.

The malting process promotes solubilization of starch and proteins hence digestibility and nutritive value of the grains. The action of proteolytic enzymes are important during malting because they release amino acids and peptides required to buffer the wort, maintain yeast growth and also facilitate the breakdown of polysaccharide protein complex during mashing. Proteins in the endosperm are strongly associated with starch granules and they exhibit different levels of compaction in cereals. It is believed that the extent of solubilization of proteins is determined by the compactness of the polysaccharide, protein complex structure rather than the enzyme levels [17]. A given cereal may be resistant to endogenous protease enzymes, but readily susceptible to an exogenous source of the enzymes. Therefore it could be conceived that a mixture of the cereals would produce mixtures of endo-and exogenous enzymes that are capable of protein solubilization of the mixed malt, such a combination of cereals, might give good malt for food applications.

The use of blends of barley and other cereals otherwise called composite flours is not a new idea [18]. Blends of maize and sorghum meals are commonly used in many African countries. The need for the standardization of grains which may be used for composite flours has been highlighted. Biochemical criteria may be useful in this regard.

\section{Conclusion}

Based on this study, it is therefore suggested that a combined enzyme analysis will be useful. Such enzyme tests will predict the acceptability and digestibility of the mixed meals, and this will also facilitate decision-making criteria for the choice of the composite flour.
Table 1. Amylase lipase and protease levels in untreated, 24 steeped and malted samples and mean deviation

\begin{tabular}{|c|c|c|c|}
\hline $\begin{array}{l}\text { Samples \& } \\
\text { treatment }\end{array}$ & $\begin{array}{l}\text { Amylase(units } / \mathbf{m} \\
\text { g protein) }\end{array}$ & $\begin{array}{l}\text { Lipase(units/mg } \\
\text { protein) }\end{array}$ & $\begin{array}{l}\text { Protease(units } \\
\text { /mg protein) }\end{array}$ \\
\hline \multicolumn{4}{|l|}{ Barley } \\
\hline Untreated & $7.3+1.06^{*}$ & $100.0+$ & $256.7+11.5$ \\
\hline 24h Steeped & $6.0+0.06$ & $113.3+5.8$ & $186.7+11.5$ \\
\hline 48h sprout & $118.8+5.3^{b}$ & $186.7+7.6^{\mathrm{a}}$ & $313.3+11.5^{\mathrm{a}}$ \\
\hline \multicolumn{4}{|l|}{ Maize } \\
\hline Untreated & $4.0+0.5$ & $73.3+5.8$ & $2067+5.8$ \\
\hline 24 steeped & $2.7+0.3$ & $86.7+5.8$ & $180.0+20.0$ \\
\hline 48h sprout & $35.3+1.2^{\mathrm{a}}$ & $256.7+15.3^{b}$ & $303.3+11.5^{\mathrm{a}}$ \\
\hline \multicolumn{4}{|l|}{ Millet } \\
\hline Untreated & $2.2+0.3$ & $86.7+5.8$ & $296.7+5.8$ \\
\hline $24 \mathrm{~h}$ steeped & $5.3+1.0$ & $200.0+10.0$ & $256.7+32.1$ \\
\hline $48 \mathrm{~h}$ sprout & $31.2+0.3^{\mathrm{a}}$ & $233.3+11.5^{\mathrm{b}}$ & $293.3+5.8^{b}$ \\
\hline \multicolumn{4}{|l|}{ Rice } \\
\hline Untreated & $2.2+0.3$ & $86.7+5.8$ & $296.7+5.8$ \\
\hline 24 steeped & $2.3+0.3$ & $103.3+5.8$ & $3.36 .7+11.5$ \\
\hline 48 sprout & $40.7+3.1^{\mathrm{a}}$ & $150.7+5.1^{\mathrm{a}}$ & $373.3+11.5^{b}$ \\
\hline \multicolumn{4}{|l|}{ Sorghum } \\
\hline Untreated & $4.0+0.12$ & $73.3+11.5$ & $186.3+5.8$ \\
\hline $24 \mathrm{~h}$ steeped & $5.3+0.3$ & $83.3+5.8$ & $183.3+5.8$ \\
\hline 48h sprout & $32.0+2.0^{\mathrm{a}}$ & $188.3+2.9^{\mathrm{a}}$ & $303.3+5.8^{\mathrm{a}}$ \\
\hline \multicolumn{4}{|l|}{ Wheat } \\
\hline Untreated & $2.0+0.1$ & $80.0+10.0$ & $333.3+15.3$ \\
\hline 24 steeped & $23.3+3.1$ & $106.7+5.8$ & $263.3+5.8$ \\
\hline $48 \mathrm{~h}$ sprouted & $52.3+2.3^{\mathrm{b}}$ & $195.0+5.0^{\mathrm{a}}$ & $603.7+11.5^{b}$ \\
\hline
\end{tabular}

* All values are Means and Standard Deviation of three Determinations. Values with different superscripts $(a, b)$ vertically differs significantly $(\mathrm{p}<0.05)$

Table 2. Percentage similarities between barley and other cereals $48 \mathrm{~h}$ sprouted based on the three enzymes

\begin{tabular}{lll}
\hline Treatment & Barley and other cereals & Percentage (100 \%) \\
\hline 48h sprouted & Barley and maize & 73.7 \\
48 sprouted & Barley and millet & 75.7 \\
48 sprouted & Barley and rice & 71.91 \\
48 sprouted & Barley and sorghum & 84.21 \\
48 sprouted & Barley and wheat & 41.11 \\
\hline
\end{tabular}

Percentage similarities were calculated from the mean deviation of the values obtained of the other cereals to barley as described in the text.

\section{References}

[1] Briggs, D.E. (1998). Malt and Malting. 1st Ed. Blackie Academic and Professional, London.

[2] Ayenor, G.S and Ocloo, F.C.K. (2007). Physicochemical changes and diastase activity associated with germinating paddy rice (PSB. Rc 34). African Journal of food Science. 1; 037-041.S

[3] Sripriya, G., Anthony, U. and Chandra, T.S. (1997). Changes in carbohydrate, free amino acids, organic acids, phytate and $\mathrm{HCl}$ extractability of minerals during germination and fermentation finger millet (Eleusine coracana)

[4] Malleshi G and Desikachar M.S.R. (1986) Studies on the comparative malting characteristics of some tropical cereals and millets. Journal of the Institute of Brewing. 92; 174-176. 
[5] Novellie, L. (1977). Beverages from sorghum and millet for human food, May 11-12, 1976, Tropical Products Institute, Londin, pp: 73-77.

[6] Mahesh G., Nissreen, A. and Eimear G. (2010). Barley for brewing: characteristic changes during malting, brewing and applications of its by-products. Comprehensive Rewiews in food Science and Food Safety. 9; 318-328.

[7] Palmer, G.H.(1979). Adjuncts in brewing and distilling. Proceedings of Second Aviemore conference of the Institute of Brewing (Eds. Campbell, I. and Poist, F.G.) PP 24-45.

[8] Mao, W.W. and Kinsella, J.E.(1981). Amylase activity in banana fruit, properties and changes in activity with ripening. Journal of Food Science 46: 1400.

[9] Chaudhry, K. (1989). Biochemical Techniques. J.P. Brothers Medical Publishers New Delhi (India). Pp 145-149.

[10] Plummer, D.T. (1978). An introduction to Practical Biochemistry ( $2^{\text {nd }}$ edition) McGraw- Hill (UK) pp225-254.

[11] Ladizinsky, G. and Hymowitz, T. (1979). Seed protein electrophoresis in Taxonomic and Evolution studies. Theoretical Applications of Genetics 54: 146-151.

[12] Dewar, J., Taylor, J.R.N. and Berjak, p. (1997). Determination of improved steeping conditions for sorghum malting. Journal of Cereal Science. 26; 129-136.
[13] Akoma, O., Onouha, S.A., Ajiboye, M.O., Akoma, A.O. and Alawoki, A.M. (2002). The nutritional and sensory quality characteristics of Kunun-zaki produced with the addition of hydrolytic enzymes from malted rice (Oryza sativa)

[14] Palmer, G.H.(1989). Cereals in malting and brewing. Journal of Cereal Science Technology 17: 312-367

[15] Palmer, G.H.(1985). Influence of Cell wall structure in enzymic breakdown of the endosperm of germinated barley. Journal of the Institute of Brewing. 47: 461-470.

[16] Koleoso, A.O. and Olatunji, O.O. (1992). Sorghum malt/Adjunct replacement in clear (lager) beer: policy and practice in Nigeria: Utilization of sorghum and malt ( Gomez, M.J., House, L.R. Rooney, L.W. and Dendy, D.A.V edn) Patancheru, India pp 41-45

[17] Palmer, G.H. and Shirakashi, Y.H. (1985). Influence of enzymic distribution on endosperm breakdown (modification) during malting. Journal of the American Society of Brewing Chemists, 43: 17-28.

[18] Dendy, D.A.V.(1992). Composite flour, Past, Present and Future: A review with special emphasis on the place of composite flour in the Semi-arid zones: In utilization of sorghum and millet (Gomez, M.I., House, L.R. Rooney, L.W and D.A.V edn) ICRISAT India pp 67-73 